\title{
Etiological study of esophageal squamous cell carcinoma in an endemic region: a population-based case control study in Huaian, China
}

\author{
Zemin Wang1, Lili Tang1, Guiju Sun², Yuntian Tang1, Yin Xie², \\ Shaokang Wang ${ }^{2}$, Xu Hu${ }^{3}$, Weimin $\mathrm{Gao}^{1}$, Stephen B Cox ${ }^{1}$ and Jia- \\ Sheng Wang*1
}

\begin{abstract}
Address: ${ }^{1}$ Department of Environmental Toxicology and the Institute of Environmental and Human Health, Texas Tech University Lubbock, Texas, USA, ${ }^{2}$ Southeast University, Nanjing, Jiangsu, P.R. China and ${ }^{3}$ Center for Disease Control and Prevention, Chuzhou Branch, Huaian, Jiangsu, P.R. China

Email: Zemin Wang - zemin.wang@tiehh.ttu.edu; Lili Tang - lili.tang@tiehh.ttu.edu; Guiju Sun - gjsun@seu.edu.cn; Yuntian Tang - yuntian.tang@tiehh.ttu.edu; Yin Xie - yinxie7988@163.com; Shaokang Wang - wangshaokang@gmail.com; XuHu -huxu@163.com; Weimin Gao - weimin.gao@tiehh.ttu.edu; Stephen B Cox - stephen.cox@tiehh.ttu.edu; JiaSheng Wang* - js.wang@ttu.edu

* Corresponding author
\end{abstract}

Published: 15 December 2006

BMC Cancer 2006, 6:287 doi:10.1 186/1471-2407-6-287
Received: 14 June 2006

Accepted: 15 December 2006

This article is available from: http://www.biomedcentral.com//47I-2407/6/287

(c) 2006 Wang et al; licensee BioMed Central Ltd.

This is an Open Access article distributed under the terms of the Creative Commons Attribution License (http://creativecommons.org/licenses/by/2.0), which permits unrestricted use, distribution, and reproduction in any medium, provided the original work is properly cited.

\begin{abstract}
Background: Continuous exposure to various environmental carcinogens and genetic polymorphisms of xenobiotic-metabolizing enzymes (XME) are associated with many types of human cancers, including esophageal squamous cell carcinoma (ESCC). Huaian, China, is one of the endemic regions of ESCC, but fewer studies have been done in characterizing the risk factors of ESCC in this area. The aims of this study is to evaluate the etiological roles of demographic parameters, environmental and food-borne carcinogens exposure, and XME polymorphisms in formation of ESCC, and to investigate possible gene-gene and gene-environment interactions associated with ESCC in Huaian, China.

Methods: A population based case-control study was conducted in 107 ESCC newly diagnosed cases and 107 residency- age-, and sex-matched controls in 5 townships of Huaian. In addition to regular epidemiological and food frequency questionnaire analyses, genetic polymorphisms of phase I enzymes CYPIAI, CYPIBI, CYP2A6, and CYP2EI, and phase II enzymes GSTMI, GSTTI, GSTPI, and microsomal epoxide hydrolase (EPHX) were assessed from genomic DNA using PCR based techniques.

Results: Consuming acrid food, fatty meat, moldy food, salted and pickled vegetables, eating fast, introverted personality, passive smoking, a family history of cancer, esophageal lesion, and infection with Helicobacter pylori were significant risk factors for ESCC $(P<0.05)$. Regular clean up of food storage utensils, green tea consumption, and alcohol abstinence were protective factors for ESCC $(P<0.01)$. The frequency of the GSTTI null genotype was higher in cases (59.4\%) compared to controls (47.2\%) with an odds ratio (OR) of 1.68 and $95 \%$ confidence interval $(\mathrm{Cl})$ from 0.96 to $2.97(\mathrm{P}=0.07)$, especially in males $(\mathrm{OR}=2.78 ; 95 \% \mathrm{Cl}=\mathrm{I} .22-6.25 ; \mathrm{P}=0.0 \mathrm{I})$. No associations were found between polymorphisms of CYPIAI, CYPIBI, CYP2A6, CYP2EI, GSTMI, GSTPI, and EPHX and ESCC (P $>0.05$ ).

Conclusion: Our results demonstrated that dietary and environmental exposures, some demographic parameters and genetic polymorphism of GSTTI may play important roles in the development of ESCC in Huaian area, China.
\end{abstract}




\section{Background}

Esophageal cancer is the eighth most commonly occurring cancer and the sixth leading cause of cancer deaths in the world, with the majority of cases occurring in developing countries [1]. China, with 250,000 cases diagnosed yearly, lies in the "esophageal cancer belt" [2], and contributes to about half of the world's cases [3]. The prevalence of esophageal cancer varies greatly across China, but there are two major endemic areas: the southern Taihang Mountain area (Linxian, Henan Province) and the northern Jiangsu area. In the northern Jiangsu area, the esophageal cancer incidence is over $80 / 100,000$ which is six times greater than the national average rate $(13 / 100,000)$. Many studies have been conducted in the southern Taihang Mountain area; however, despite very distinct geographic environments, fewer studies have been done in the northern Jiangsu area. Since esophageal squamous cell carcinoma (ESCC) represents more than 99\% of esophageal cancer cases in China [4], this study focused only on ESCC.

Previous epidemiological studies have demonstrated that exposure to environmental carcinogens plays a significant role in the etiology of ESCC [5-7]. The recognized risk factors for ESCC include excessive use of tobacco, alcohol consumption, and the consumption of salt-pickled, saltcured or moldy foods [8-10]. Other factors associated with increased risk of ESCC include vitamin and trace mineral deficiencies [11]. On the other hand, genetic polymorphisms may also play an important role in the development of ESCC and in determining individual susceptibility to carcinogens. Many studies have suggested that polymorphisms in xenobiotic-metabolizing enzymes (XME) including phase I enzymes such as CYP1A1, CYP1B1, CYP2A6 and CYP2E1, and phase II enzymes such as GSTM1, GSTT1, GSTP1, and microsomal epoxide hydrolase (EPHX) may confer different risks of susceptibility to cancer [12-20], including ESCC [21-23]. For example, genetic variations, including CYP2E1 c1/c1 allele, GSTM1 and GSTT1 non-null genotype and EPHX slow allele, were associated with increased risk of ESCC, while CYP1A1 3' polymorphism (variant allele) may be one of the protective factors for ESCC [22,23]. It is clear that many cancers including ESCC, are the result of complex interactions between inherited and environmental factors [24].

Although extensive studies have been carried out during the last two to three decades in the southern Taihang Mountain area $[8,11,22,23]$, data are scarce from the northern Jiangsu area [21]. In the present study, we conducted a population based case-control study of ESCC in the Huaian area. In addition to regular epidemiological and food frequency questionnaire analyses, we investigated the polymorphisms of several phase I metabolic enzymes, including CYP1A1, CYP1B1, CYP2A6, and CYP2E1, and phase II metabolic enzymes, including GSTM1, GSTT1, GSTP1 and EPHX, which are believed to be involved in the metabolism of the environmental carcinogens for many types of cancers. The overall goal of this study is to evaluate the etiological roles of dietary carcinogen exposure and XEM polymorphisms, and to investigate possible gene-gene and gene-environment interactions associated with ESCC in this high risk area.

\section{Methods \\ Study subjects}

This population based matched case-control study consisted of 107 patients with ESCC and 107 healthy controls. All subjects were unrelated ethnic Han Chinese and residents in 5 townships of Chuzhou District, which were located at the north side of the General Irrigation Canal, Huaian City, Jiangsu Province, China. Based on a database at the malignant tumor registry of Huaian Center for Disease Control and Prevention (CDC), all cases were newly diagnosed with primary ESCC between 2002 and 2003. Cases were diagnosed at local hospitals and confirmed by endoscopy, X-ray or clinical histopathology. Control subjects were randomly selected healthy individuals confirmed by physical examination, clinical and biochemical analyses during the same period of case recruitment. Eligible controls included individuals without a history of cancer and were matched to cases on the basis of age ( \pm 5 years), gender, and residency. Informed consent was obtained from each subject. The study protocol was approved by the Institutional Review Boards of the Texas Tech University, the Southeast University, and Huaian CDC for human subject protection. Sample collection, storage and shipment were complied with guidelines of both Chinese and US governments.

\section{Study procedures}

A unified questionnaire, administered by trained personnel, was used to obtain study information. The questionnaire included demographic and residential characteristics, consisting of age, gender, height, weight, personal medical history, family cancer history, cigarette smoking, alcohol drinking, personality, dietary behaviors, green tea consumption, and exposure to pesticides and water-borne toxicants. Data on cigarette smoking included age started and ceased, number of cigarettes per day and duration. Participants were defined as current smokers if they smoked at least one cigarette per day for at least six months consecutively before the diagnosis for cases or to the date the controls were interviewed. Alcohol history included general information such as age started and ceased, as well as specific questions about the types of alcohol consumed, such as beer, yellow rice wine, red wine and liquor. Drinking status was defined as drinking at least once per day for at least six months continuously. 
The personality was classified into 3 categories including optimistic (or extrovert), relative optimistic (intermediate extrovert), and introvert. Extrovert was defined as sociable, active, assertive, energetic, animated, enthusiastic outgoing, impulsive, emotionally expressive, talkative, act before thinking, and broad experience. Introvert was defined as shy, unsociable, often appear reserved, quiet and thoughtful, usually do not have many friends, and have difficulties in making new contacts, like concentration and quiet. Esophageal lesion in our study was defined as including one or more of the following clinically diagnosed esophagus diseases or changes: 1) chronic esophagitis; 2) reflux esophagitis; 3) esophageal epithelium regeneration; 4) esophageal epithelium metaplasia; 5) esophageal polyps; and 6) esophageal erosion. All subjects were asked to fill out a quantitative food frequency questionnaire on 8 categories including 1) staple diet; 2) fried food; 3) pickled and salty food; 4) animal meat, egg and milk; 5) bean and bean product; 6) vegetables; 7) fresh fruits; and 8) nuts and dried fruits. A total of 120 food items were included in these 8 categories. These were considered representative of the usual diets of local residents.

In addition to epidemiological and food frequency questionnaires, $7 \mathrm{~mL}$ blood samples were collected from each subject, and separated into white blood cell (WBC) and plasma. Serological markers of Hepatitis B virus and Helicobacter pylori (HP) infection were detected. All samples were stored at $-80^{\circ} \mathrm{C}$ and then shipped to the Institute of Environmental and Human Health, Texas Tech University for further analysis.

\section{DNA extraction and polymorphism analysis}

Genomic DNA was extracted from WBC using the Qiagen QIAamp DNA Blood Mini Kit (QIAGEN Inc. Valencia, CA, USA) according to the procedure provided by the manufacture. Ten polymorphic alleles in 8 genes were investigated using PCR based techniques (Table 1). The CYP1A1 3'-UTR, CYP1A1 exon7, CYP1B1, CYP2E1, GSTP1,
EPHX113 and EPHX1 genotypes were analyzed using PCR-RFLP methods as described previously [22,25-29]. A two step PCR was used for detecting the CYP2A6 deletion allele [30]. A modified multiplex PCR method was used for genotyping GSTM1, GSTT1 [23]. Briefly, the PCR was performed in a $25 \mu \mathrm{L}$ reaction mixture containing $50 \mathrm{ng}$ genomic DNA template, $1.5 \mathrm{mM} \mathrm{MgCl}_{2}, 0.3 \mathrm{mM}$ of each deoxynucleotide triphosphate (dNTPs) (MBI Fermentas Inc., Hanover, MD, USA), $0.8 \mu \mathrm{M}(20 \mathrm{pmol})$ of each primer, 2.5 $\mu \mathrm{L}$ 10X PCR buffer and 1.25 Units Platinum Taq polymerase (Invitrogen, Carlsbad, CA, USA). A programmable thermocycler (PTC-200, MJ Research, Inc., MA, USA) was used. In each reaction, amplification of the beta-globin gene was used as an internal standard. The amplification protocol was set up for an initial denaturation of $2 \mathrm{~min}$ at $95^{\circ} \mathrm{C}$, followed by a total of 30 cycles of $15 \mathrm{sec}$ at $94^{\circ} \mathrm{C}, 30 \mathrm{sec}$ at $61^{\circ} \mathrm{C}$ and $45 \mathrm{sec}$ at $72^{\circ} \mathrm{C}$. A final extension step was performed at $72^{\circ} \mathrm{C}$ for $5 \mathrm{~min}$. The amplified products were visualized by electrophoresis on ethidium bromide-stained $2.0 \%$ MetaPhor Agarose gel (Cambrex Bio Science Inc., Walkersville, MD, USA) in $1 \mathrm{X}$ TAE buffer.

For quality control, $10 \%$ of the samples were randomly selected and regenotyped for all of the selected genes, and the results were $100 \%$ concordant.

\section{Statistical analyses}

Database on epidemiological and food intake frequency questionnaire data was established before analyses. Genotype frequencies among cases and controls were compared with values predicted by the Hardy-Weinberg equilibrium using $\chi^{2}$ test. The association between individual variables including demographic characteristics, dietary and environmental factors, or genetic polymorphisms, and risk of ESCC was estimated by conditional logistic regression. Odds ratios (ORs) and their 95\% confidence interval (CIs) were determined. The simultaneous effects of statistically significant variables on cancer risk were then examined using multivariable conditional

Table I: Characteristics of selected genes in this study

\begin{tabular}{|c|c|c|c|c|c|}
\hline Loci & Gene location & Genotypes & Restriction enzymes & Methods & References \\
\hline CYPIAI & 3'-flanking & $6235 T$ to $C$ & Mspl & PCR-RFLP & Hong et al, 1998 [25] \\
\hline CYPIAI & exon 7 & lle462Val & Nocl & PCR-RFLP & London et al, 2000 [27] \\
\hline CYPIBI & exon 3 & Val432Leu & Eco57l & PCR-RFLP & Saintot et al, 2004 [28] \\
\hline CYP2A6 & exon7-9 & Deletion & - & Two step-PCR & Tan et al, 200l [30] \\
\hline CYP2EI & 5'-flanking & $c / / c 2$ & Rsal & PCR-RFLP & Tan et al, 2000 [22] \\
\hline GSTMI & Whole gene & GSTMI(-)I & No amplification & Multiplex PCR & Wang et al, 2003 [23] \\
\hline GSTTI & Whole gene & GSTTI(-)I & No amplification & Multiplex PCR & Wang et al, 2003 [23] \\
\hline GSTPI & exon 5 & lle I05Val & Alw261 & PCR-RFLP & Harries et al, 1997 [26] \\
\hline EHPX $/ 13$ & exon 3 & Tyr I I 3 His & Tth I I II & PCR-RFLP & de Jong et al, 2003 [29] \\
\hline$E P H X 139$ & exon 4 & His / 39Arg & Rsal & PCR-RFLP & de Jong et al, 2003 [29] \\
\hline
\end{tabular}

Inull genotype. 
logistic regression model. Interactions between genotypes and genotypes or between genotypes and environmental factors were also estimated by using conditional logistic regression. A p-value of $\leq 0.05$ was considered statistically significant. The statistical analyses were performed with STATA 6.0 .

\section{Results}

\section{Subject characteristics}

Demographic information of study subjects was summarized in Table 2. Mean age, gender distributions, family income, tobacco smoking, and alcohol drinking status did not differ between cases and controls $(P>0.05)$. Passive smoking and a family history of cancer were found to be risk factors for ESCC $(\mathrm{P}<0.05)$. The percentages for optimistic, relative optimistic, and introvert personality were $49 \%(104 / 214), 41 \%(87 / 214)$, and 10\% (23/214), respectively. Five percent $(11 / 214)$ individuals had esophageal lesion and 34\% (72/214) had HP infection. Individuals with an introverted personality, esophageal lesion, or previous HP infection were more likely to develop ESCC $(\mathrm{P} \leq 0.05$, Table 3$)$.

Associations of dietary behavioral factors and risk of ESCC Among the 32 dietary behavioral factors in the epidemiological questionnaire, 12 variables showed statistically significant associations with ESCC (Table 3). Eating fast, eating fatty meat, pickled vegetables, acrid, salty, and moldy food were all risk factors of ESCC $(\mathrm{P}<0.05)$; whereas, green tea consumption at $60 \sim 80^{\circ} \mathrm{C}$, regular clean up of food storage utensils, and alcohol abstinence were protective factors of ESCC $(\mathrm{P}<0.01)$.

\section{Associations of XME polymorphisms with risk of ESCC}

Genotype frequencies did not deviate from the HardyWeinberg equilibrium among cases and controls $(\mathrm{P}>$
0.05). Allele frequencies of phase I metabolic enzymes (including CYP1A13'-UTR, CYP1A1 exon7, CYP1B1, CYP2A6 (del), and CYP2E1) and phase II metabolic enzymes (including GSTM1, GSTP1, EPHX113, and EPHX139) were not significantly different between cases and controls $(P>0.05)$ (Figure $1 \mathrm{a})$. In addition, no significant association was found between these genotypes and ESCC within either males or females (Figure 1b 1c). However, GSTT1 genotype was marginally associated with ESCC $(\mathrm{OR}=1.68 ; 95 \% \mathrm{CI}=0.96-2.97 ; \mathrm{P}=0.07)$. This association was more significant in male patients $(\mathrm{OR}=$ 2.78; 95\% CI $=1.22-6.25 ; \mathrm{P}=0.01$ ) (Figure $1 \mathrm{~b}$ ).

\section{Multivariable conditional logistic analyses}

When examined simultaneously, a family history of cancer, esophageal lesions, eating fast, and HP infection increased the risk of developing ESCC (Table 4), while regular clean up of food storage utensils and tea consumption were shown to be important protective factors with ORs of $0.11(95 \% \mathrm{CI}=0.02-0.49 ; \mathrm{P}<0.01)$ and 0.13 (95\% CI $=0.03-0.62 ; \mathrm{P}=0.01)$, respectively.

Analyses of gene-gene and gene-environment interactions Gene-gene and gene-environment interactions were examined by conditional logistic regression and no statistical significances were found $(P>0.05)$.

\section{Discussion}

In the present study, introverted personality, passive smoking, a family history of cancer, esophageal lesion, HP infection, eating fast, fatty meat consumption, pickled vegetables intake, moldy food intake, favor to salty and acrid food were all associated with increased risk of ESCC. However, regular clean up of food storage utensils, alcohol abstinence lasted for more than half a year, and tea drinking were protective for ESCC. Among the factors

Table 2: Demographic characteristics of the case and control populations

\begin{tabular}{|c|c|c|c|c|}
\hline & Case n (\%) & Control n (\%) & $\mathrm{OR}(95 \% \mathrm{Cl})$ & $P$ \\
\hline Male & 60 & 60 & & \\
\hline Female & 47 & 47 & & \\
\hline Mean age (yr) & $62.9 \pm 8.19$ & $62.4 \pm 8.35$ & & \\
\hline \multicolumn{5}{|l|}{ Smoking status } \\
\hline None-smoker & $40(37.4)$ & $43(40.2)$ & 1.00 & \\
\hline Smoker & $67(62.6)$ & $64(59.8)$ & $1.14(0.64-2.04)$ & 0.67 \\
\hline \multicolumn{5}{|l|}{ Passive smoking } \\
\hline No & $37(34.6)$ & $54(50.5)$ & 1.00 & \\
\hline yes & $70(65.4)$ & $53(49.5)$ & $2.04(1.14-3.70)$ & 0.02 \\
\hline \multicolumn{5}{|l|}{ Drinking status } \\
\hline None-drinker & $60(56.1)$ & $58(54.2)$ & 1.00 & \\
\hline Drinker & $47(43.9)$ & $49(45.8)$ & $1.06(0.77-1.43)$ & 0.70 \\
\hline \multicolumn{5}{|c|}{ Income (Yuan, Mean \pm SD) } \\
\hline Total & $486.4 \pm 425.80$ & $592.0 \pm 590.63$ & $1.0(0.99 \sim 1.0)$ & 0.10 \\
\hline Average & $127.2 \pm 98.68$ & $148.2 \pm 122.28$ & $0.998(0.995 \sim 1)$ & 0.15 \\
\hline \multicolumn{5}{|c|}{ Family history of cancer } \\
\hline Negative & $39(36.4)$ & $49(45.8)$ & 1.00 & \\
\hline Positive & $68(63.6)$ & $58(54.2)$ & $2.90(I .4 I-5.95)$ & $<0.01$ \\
\hline
\end{tabular}


Table 3: Univariate conditional logistic regression analyses of dietary and environmental factors and ESCC

\begin{tabular}{|c|c|c|}
\hline Variable & OR $(95 \% \mathrm{Cl})$ & $P$ \\
\hline Personality & I.89(1.07 3.34) & 0.03 \\
\hline Esophageal lesion & $4.5(0.97-20.83)$ & 0.05 \\
\hline HP infection & $2.00(1.10 \sim 3.64)$ & 0.02 \\
\hline Eating fast & $3.25(1.70 \sim 6.21)$ & $<0.01$ \\
\hline Favor salty food & $2.00(1.05 \sim 3.80)$ & 0.03 \\
\hline Favor acrid food & $2.08(1.07 \sim 4.03)$ & 0.03 \\
\hline Fatty meat & $3.00(1.19-7.56)$ & 0.02 \\
\hline Pickled vegetables & $2.55(1.27-5.11)$ & $<0.01$ \\
\hline Moldy food intake & $2.27(1 . \mid 2-4.61)$ & 0.02 \\
\hline Clean up of storage utensils & $0.27(0.12-0.62)$ & $<0.01$ \\
\hline Green tea consumption & $0.25(0.09 \sim 0.67)$ & $<0.01$ \\
\hline Alcohol abstinence & $0.13(0.03 \sim 0.54)$ & $<0.01$ \\
\hline
\end{tabular}

associated with ESCC in this study, an introverted personality type, clean up of food storage utensils, and alcohol abstinence are first reported. Other major findings are consistent with previous studies conducted in China and elsewhere [31-33] including studies conducted in the Huaian area $[34,35]$. For instance, previous epidemiological surveys have shown that people in this area used to consume a lot of salted food and pickled vegetables. These foods are a rich source of nitrosamine compounds, and have been reported to be risk factors for ESCC [36]. Moldy foods are frequently contaminated by fungal toxins, and it has long been reported that mycotoxins, especially Fumonisin $\mathrm{B}_{1}\left(\mathrm{FB}_{1}\right)$, are associated with ESCC [37]. This may also be an explanation for our finding that maintaining clean storage utensils reduces the risk of ESCC. Damp and dirty environments favor the growth of mold and mildew, and regular clean up of the utensils may be a good habit to prevent food from developing mildew and molds. Eating fast, as well as frequently consuming acrid foods, which are common physical stimulations to the esophagus, most often will lead to the chronic esophagitis. This has been considered the earliest tissue perturbation in the progressive process leading to malignant transformation of the squamous epithelium of the esophagus [38].

We found that passive smoking is significantly associated with increased risk of ESCC. Passive smoking is a major risk factor for lung cancer, and emerging studies have shown that it may also be related to increased risk of breast cancer in women [39]. It has been suggested that passive smoking or environmental tobacco smoke (ETS), $85 \%$ of which consisted by sidestream smoke due to burning cigarette, was more risky than active smoking, and concentrations of some carcinogens are higher in sidestream than in mainstream smoke, which is exhaled by the smoker [40]. ETS has been classified as a Group A carcinogen which means it is known to cause cancer in humans [41]. The number of known carcinogens in ETS has been reported to be 69 in 2000 [42]. The role of active smoking has been examined by age started, smoking intensity, years smoked, cessation, type of tobacco, and type of cigarette. No association between active smoking and ESCC was found.

We also found that alcohol abstinence is a protective factor for ESCC. It is possible that genetic damage such as chromosome aberrations and micronuclei caused by alcohol are reversible by abstinence [43]. Although several epidemiological studies have showed that exposure to tobacco smoking and alcohol drinking are major risk factors for ESCC [44-46], we did not find any association between smoking and alcohol drinking and the risk of ESCC. It may be resulted from that men usually smoke and drink while women do not smoke or drink in this area.

Data from the present study revealed that HP infection was a risk factor for ESCC in the high risk population. However, results on HP infection and risk of ESCC have been inconsistent to date, an inverse relationship between HP infection and esophageal adenocarcinoma risk has been reported $[47,48]$. Furthermore, HP infection was protective against developing ESCC in a Taiwanese population [49]. Possible reasons for this discrepancy are not clear, and further investigation is needed.

Our study indicated that green tea is an important protective factor for ESCC, which is consistent with previous studies conducted in the same area [21] and in Shanghai, China [50]. Recent evidence suggests that the anti-oxidative and anti-inflammatory properties of green tea make it a promising agent for human cancer preventions [51]. In rats, green tea consumption prevents the esophageal carcinogenesis induced by $\mathrm{N}$-nitrosomethylbenzylamine (NMBA), which is a potent carcinogen that is frequently found in moldy food and pickled vegetables [52]. A cohort study also showed an inverse relationship between 

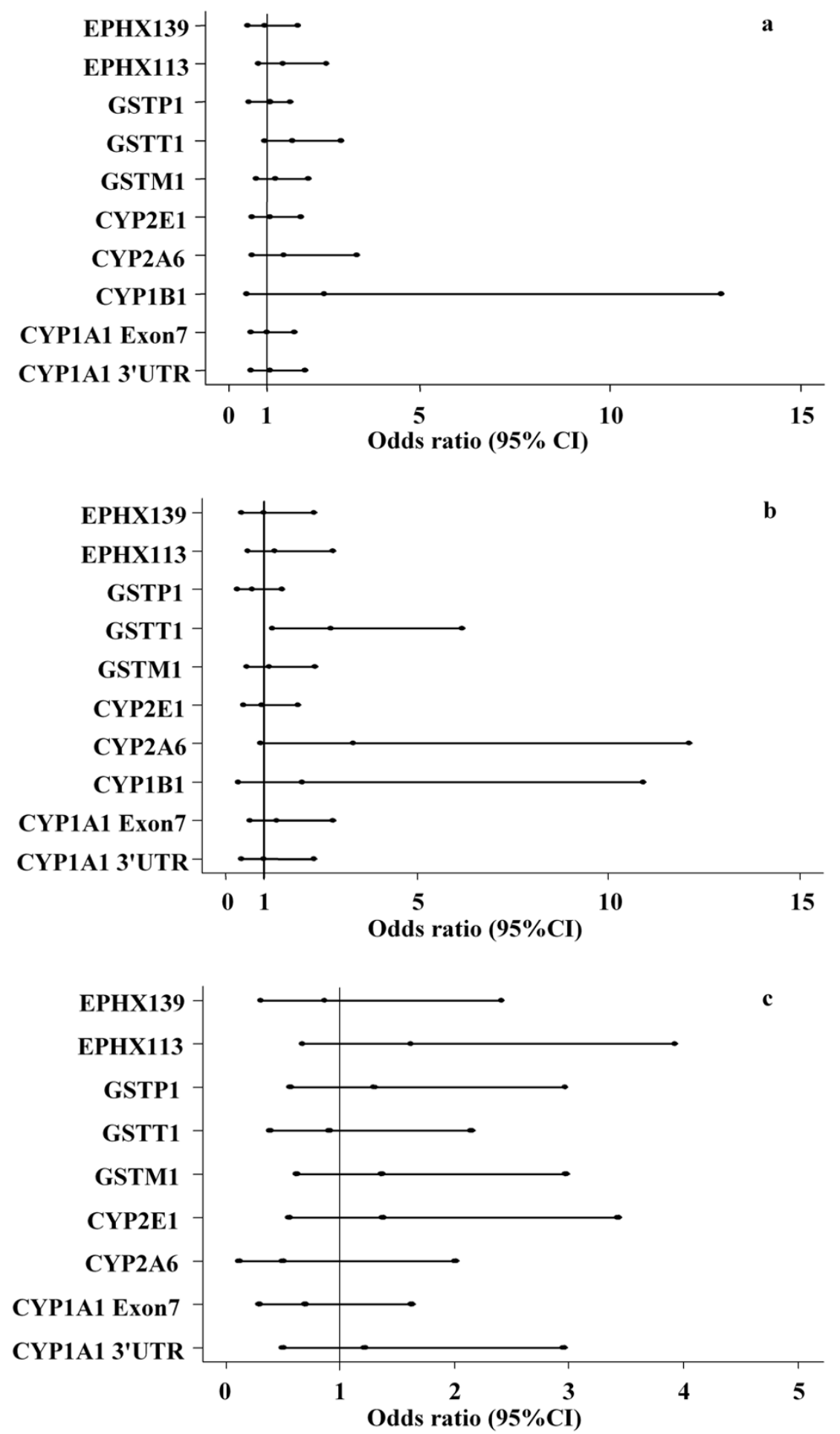

Figure I

Xenobiotic metabolizing enzyme polymorphisms and risk of ESCC. Heterozygote and homozygote variant alleles were combined for each gene and wild type was used as reference. The middle dot of each line represents an odds ratios value, the left and the right dot of each line represent the lower and upper limits of $95 \%$ confidence interval, respectively. (a) Phase I and phase II enzyme polymorphisms and risk of ESCC among the study subjects. (b) Phase I and phase II enzyme polymorphisms and risk of ESCC in male subjects. (c) Phase I and phase II enzyme polymorphisms and risk of ESCC in female subjects. 
Table 4: Multivariable conditional logistic regression analyses of risk factors for ESCC

\begin{tabular}{|c|c|c|}
\hline Variable & OR $(95 \% \mathrm{Cl})$ & $P$ \\
\hline Esophageal lesion & $11.63(1.13-119.33)$ & 0.04 \\
\hline Eating fast & $3.39(1.15-9.95)$ & 0.03 \\
\hline Utensil clean up & $0.11(0.02-0.49)$ & $<0.01$ \\
\hline Green tea consumption & $0.13(0.03-0.62)$ & 0.01 \\
\hline Family history of cancer & $3.83(1.13-12.97)$ & 0.03 \\
\hline HP infection & $3.19(1.11-9.15)$ & 0.03 \\
\hline
\end{tabular}

urinary green tea polyphenols and risk of ESCC of men [53]. One possible mechanism may be that the green tea polyphenols induce epidermal growth factor receptor inhibition in esophageal cancer cells [54]. Taken together, these findings suggest that green tea might be used as a chemoprevention agent for human esophageal cancer.

Numerous studies have investigated the association between different XME polymorphisms and ESCC, but with conflicting results [18]. In the present study, a difference was found in the distribution of GSTT1 null genotypes between cases and controls; however, the difference only approached statistical significance. This difference was more striking in the male subjects, resulting in a 2.8 fold increase in risk of ESCC compared to male subjects who carried the GSTT1 non-null genotype. This suggests that the GSTT1 null genotype may contribute to the development of ESCC in this high risk population. Although this was different from previous studies on ESCC $[22,23,55]$, it is biologically plausible because the presence of the GSTT1 null genotype leads to lower GST enzyme activity levels and, consequently, impaired detoxification of environmental or dietary carcinogens. In addition, GSTT1 null has been shown to play a role in esophageal carcinogenesis through a pathway of abnormalities in the $p 53$ tumor suppressor gene, which is highly reported in ESCC [18]. Previous data showed that CYP1A1 $\mathrm{Val} / \mathrm{Val}$ and CYP2E1 $c 1 / c 1$ genotypes were related with increased risk of ESCC [22,56]. EPHX was also reported to be associated with high susceptibility of ESCC [23]. Nevertheless, we did not find significant association between CYP1A1, CYP2E1, CYP2A6, and EPHX and ESCC. The exact reasons for these inconsistent findings remain to be elucidated, but it is demonstrated that the variation in enzyme activity with ethnicity and gender may contribute to the differences in effects on the risk of cancers [57].

In order to find an overall risk for ESCC, variables with statistical significance in univariate conditional logistic regression were analyzed in a multivariable model. Esophageal lesion, eating fast, a family history of cancer, and HP infection were risk factors for ESCC $(\mathrm{P}<0.05)$, while clean up of storage utensils and green tea consumption were protective factors for ESCC $(P<0.05)$. Personal character, fatty meat intake, pickled vegetables intake, and alcohol abstinence were not statistically significant in the multivariable model which might be due to their colinearity with other variables in the multivariable analysis. For instance, eating fast and pickled vegetables intake was highly correlated $(\mathrm{P}<0.05$, data not shown). Although, gene-gene and gene-environment interactions have been reported for ESCC $[22,58]$, we did not find such interactions in our study, which might be related to the smaller sample size in our study.

\section{Conclusion}

The present study indicated that fatty meat consumption, eating fast, consuming pickled vegetables, moldy food intake, preference for salty and acrid food along with esophageal lesion, HP infection, passive smoking, and a family history of cancer are risk factors for ESCC in Huaian area, China. Regular cleaning of food storage utensils, green tea consumption, and alcohol abstinence are important protective factors for ESCC in this high risk population. In addition, there was a significant association between the GSTT1 null genotype and risk of ESCC in male subjects. One potential limitation of the current study is the relatively smaller sample size, which may reduce statistical power for detecting gene-gene and geneenvironmental differences. Hence, further studies with larger sample size and prospective cohort are mandated to confirm the present findings.

\section{Abbreviations}

$\mathrm{XME}=$ xenobiotic-metabolizing enzymes; $\mathrm{ESCC}=$ esophageal squamous cell carcinoma; $\mathrm{CYP}=$ cytochrome P450; GST = glutathione S-transferase $;$ EPHX = microsomal epoxide hydrolase; $\mathrm{PCR}=$ polymerase chain reac- 
tion; RFLP = restriction fragment length polymorphism; $\mathrm{OR}=$ odds ratio; $\mathrm{CI}=$ confidence interval; $\mathrm{HP}=$ helicobacter pylori.

\section{Competing interests}

The author(s) declare that they have no competing interests.

\section{Authors' contributions}

ZW carried out the genotyping studies, participated in the statistical analysis of the data and drafted the manuscript. LT participated in the design of the study, helped to coordinate sample usage and in drafting the manuscript. GS participated in the design of the study and in the acquisition of the epidemiological data and the samples. YT participated in genomic DNA extraction. YX participated in the acquisition of the samples. SW participated in the acquisition of the samples. XH organized the epidemiological field study and participated in the acquisition of the samples. WG participated in the statistical analysis of the data and helped to draft the manuscript. SBC participated in the statistical analysis of the data and helped to draft the manuscript. J-SW conceived of the study, participated in its design, and helped to draft the manuscript. All authors read and approved the final manuscript.

\section{Acknowledgements}

This work was supported by grants CA94683 and CA90997 from NCI/NIH to Dr. Jia-Sheng Wang.

\section{References}

I. Parkin DM, Bray F, Ferlay J, Pisani P: Global cancer statistics, 2002. CA Cancer J Clin 2005, 55(2):74- 108.

2. Parkin DM, Laara E, Muir CS: Estimates of the worldwide frequency of sixteen major cancers in 1980. Int J Cancer 1988, $41(2):$ 184-197.

3. Yang L, Parkin DM, Li L, Chen Y: Time trends in cancer mortality in China: 1987-1999. Int / Cancer 2003, 106(5):77|-783.

4. Bai SX, Zhang S, Li BQ: Primary esophageal adenocarcinoma. Chin J Oncol 1989, I I:383-385

5. Lu SH, Chui SX, Yang WX, Hu XN, Guo LP, Li FM: Relevance of Nnitrosamines to oesophageal cancer in China. IARC Sci Publ 1991:11-17.

6. Ribeiro U Jr., Posner MC, Safatle-Ribeiro AV, Reynolds JC: Risk factors for squamous cell carcinoma of the oesophagus. Br J Surg 1996, 83(9): | |74-1| 85

7. Stoner GD, Gupta A: Etiology and chemoprevention of esophageal squamous cell carcinoma. Carcinogenesis 200I, 22(II): I737-1746.

8. Yang CS: Research on esophageal cancer in China: a review. Cancer Res 1980, 40(8 Pt I):2633-2644.

9. Lin K, Shen $\mathrm{W}$, Shen Z, Wu Y, Lu S: Dietary exposure and urinary excretion of total $\mathbf{N}$-nitroso compounds, nitrosamino acids and volatile nitrosamine in inhabitants of high- and low-risk areas for esophageal cancer in southern China. Int J Cancer 2002, I02(3):207-2II.

10. Tran GD, Sun XD, Abnet CC, Fan JH, Dawsey SM, Dong ZW, Mark SD, Qiao YL, Taylor PR: Prospective study of risk factors for esophageal and gastric cancers in the Linxian general population trial cohort in China. Int / Cancer 2005, I I 3(3):456-463.

II. Yang CS, Sun Y, Yang QU, Miller KW, Li GY, Zheng SF, Ershow AG, Blot W], Li JY: Vitamin A and other deficiencies in Linxian, a high esophageal cancer incidence area in northern China. J Natl Cancer Inst 1984, 73(6): | 449- | 453.
12. Vineis $P$ : Individual susceptibility to carcinogens. Oncogene 2004, 23(38):6477-6483.

13. Lu XM, Zhang YM, Lin RY, Arzi G, Wang X, Zhang YL, Zhang Y, Wang $\mathrm{Y}$, Wen $\mathrm{H}$ : Relationship between genetic polymorphisms of metabolizing enzymes CYP2EI, GSTMI and Kazakh's esophageal squamous cell cancer in Xinjiang, China. World J Gastroenterol 2005, I I (24):365I-3654.

14. Ingelman-Sundberg M: Human drug metabolising cytochrome P450 enzymes: properties and polymorphisms. Naunyn Schmiedebergs Arch Pharmacol 2004, 369(I):89-104.

15. Autrup H: Genetic polymorphisms in human xenobiotica metabolizing enzymes as susceptibility factors in toxic response. Mutat Res 2000, 464(I):65-76.

16. Vogl FD, Taioli E, Maugard C, Zheng W, Pinto LF, Ambrosone C, Parl FF, Nedelcheva-Kristensen V, Rebbeck TR, Brennan P, Boffetta P: Glutathione S-transferases MI, TI, and PI and breast cancer: a pooled analysis. Cancer Epidemiol Biomarkers Prev 2004, |3(9): | 473-1479.

17. Zielinska E, Zubowska M, Bodalski J: Polymorphism within the glutathione S-transferase $P I$ gene is associated with increased susceptibility to childhood malignant diseases. Pediatr Blood Cancer 2004, 43(5):552-559.

18. Casson AG, Zheng Z, Chiasson D, MacDonald K, Riddell DC, Guernsey JR, Guernsey DL, McLaughlin J: Associations between genetic polymorphisms of Phase I and II metabolizing enzymes, p53 and susceptibility to esophageal adenocarcinoma. Cancer Detect Prev 2003, 27(2): 139-146.

19. Zhang JH, Jin X, Li Y, Wang R, Guo W, Wang N, Wen DG, Chen ZF, Kuang G, Wei LZ, Wang SJ: Epoxide hydrolase Tyr I I 3His polymorphism is not associated with susceptibility to esophageal squamous cell carcinoma in population of North China. World J Gastroenterol 2003, 9( I 2):2654-2657.

20. Oude Ophuis MB, Manni JJ, Peters WH: Glutathione S-transferase TI null polymorphism and the risk for head and neck cancer. Acta Otolaryngol 2006, I 26(3):3 I I-3I7.

21. Gao CM, Takezaki T, Wu JZ, Li ZY, Liu YT, Li SP, Ding JH, Su P, Hu $X$, Xu TL, Sugimura $H$, Tajima K: Glutathione-S-transferases MI (GSTMI) and GSTTI genotype, smoking, consumption of alcohol and tea and risk of esophageal and stomach cancers: a case-control study of a high-incidence area in Jiangsu Province, China. Cancer Lett 2002, 188(I-2):95-102.

22. Tan W, Song N, Wang GQ, Liu Q, Tang HJ, Kadlubar FF, Lin DX: Impact of genetic polymorphisms in cytochrome P450 2E I and glutathione S-transferases $M I, T I$, and $P I$ on susceptibility to esophageal cancer among high-risk individuals in China. Cancer Epidemiol Biomarkers Prev 2000, 9(6):55I-556.

23. Wang LD, Zheng S, Liu B, Zhou JX, Li YJ, Li JX: CYPIAI, GSTs and $\mathrm{mEH}$ polymorphisms and susceptibility to esophageal carcinoma: study of population from a high- incidence area in north China. World J Gastroenterol 2003, 9(7): 1394-1 397.

24. Xing D, Tan W, Lin D: Genetic polymorphisms and susceptibility to esophageal cancer among Chinese population (review). Oncol Rep 2003, 10(5): 1615-1623.

25. Hong YS, Chang JH, Kwon OJ, Ham YA, Choi JH: Polymorphism of the CYPIAI and glutathione-S-transferase gene in Korean lung cancer patients. Exp Mol Med 1998, 30(4): $192-198$.

26. Harries LW, Stubbins MJ, Forman D, Howard GC, Wolf CR: Identification of genetic polymorphisms at the glutathione $S$ transferase Pi locus and association with susceptibility to bladder, testicular and prostate cancer. Carcinogenesis 1997, I8(4):64|-644.

27. London SJ, Yuan JM, Coetzee GA, Gao YT, Ross RK, Yu MC: CYPIAI 1462 Venetic polymorphism and lung cancer risk in a cohort of men in Shanghai, China. Cancer Epidemiol Biomarkers Prev 2000, 9(9):987-991.

28. Saintot M, Malaveille C, Hautefeuille A, Gerber M: Interaction between genetic polymorphism of cytochrome P450-IB I and environmental pollutants in breast cancer risk. Eur J Cancer Prev 2004, I 3(I):83-86.

29. de Jong DJ, van der Logt EM, van Schaik A, Roelofs HM, Peters WH, Naber TH: Genetic polymorphisms in biotransformation enzymes in Crohn's disease: association with microsomal epoxide hydrolase. Gut 2003, 52(4):547-55I.

30. Tan W, Chen GF, Xing DY, Song CY, Kadlubar FF, Lin DX: Frequency of CYP2A6 gene deletion and its relation to risk of 
lung and esophageal cancer in the Chinese population. Int J Cancer 200I, 95(2):96-I0I.

31. Li K, Yu P: Food groups and risk of esophageal cancer in Chaoshan region of China: a high-risk area of esophageal cancer. Cancer Invest 2003, 2 I (2):237-240.

32. Ke L, Ping Y, Ge H: Protective action of fresh fruit and vegetable consumption on the synergic effect of alcohol and tobacco use on esophageal cancer in South China. Nutrition 2003, 19(9):82I.

33. De Stefani E, Deneo-Pellegrini H, Ronco AL, Boffetta P, Brennan P, Munoz N, Castellsague $X$, Correa $P$, Mendilaharsu M: Food groups and risk of squamous cell carcinoma of the oesophagus: a case-control study in Uruguay. $\mathrm{Br} J$ Cancer 2003, 89(7): $|209-| 2 \mid 4$.

34. Shen $\mathrm{H}, \mathrm{Xu} \mathrm{Y}$, Shen J: Etiological relationship between pickled vegetables and esophageal cancer in Huai'an epidemic area. Acta academiae medicinae nanjing 1997, I7(2): | | 9-122.

35. Gao CM, Takezaki T, Ding JH, Li MS, Tajima K: Protective effect of allium vegetables against both esophageal and stomach cancer: a simultaneous case-referent study of a high-epidemic area in Jiangsu Province, China. Jpn J Cancer Res 1999, 90(6):6|4-62|.

36. Pickled vegetables. IARC Monogr Eval Carcinog Risks Hum 1993, 56:83-II3.

37. Abnet CC, Borkowf CB, Qiao YL, Albert PS, Wang E, Merrill AH Jr., Mark SD, Dong ZW, Taylor PR, Dawsey SM: Sphingolipids as biomarkers of fumonisin exposure and risk of esophageal squamous cell carcinoma in china. Cancer Causes Control 200I, I 2(9):82I-828.

38. Mandard AM, Hainaut P, Hollstein M: Genetic steps in the development of squamous cell carcinoma of the esophagus. Mutat Res 2000, 462(2-3):335-342.

39. Johnson KC: Accumulating evidence on passive and active smoking and breast cancer risk. Int J Cancer 2005, I I7(4):619-628.

40. Centers for Disease Control and Prevention (CDC): 1986 Surgeon General's report: the health consequences of involuntary smoking. MMWR Morb Mortal Wkly Rep 1986, 35(50):769-770.

41. Agency USEP: Respiratory health effects of passive smoking: lung cancer and other disorders. Office of Health and Environmental Assessment, Office of Research and Development, Washington, DC. 1992:EPA/600/6-90/006F.

42. International Agency for Research on Cancer: Tobacco smoke and involuntary smoking. IARC Monogr Eval Carcinog Risks Hum 2004, 83: $1-1438$.

43. Castelli E, Hrelia P, Maffei F, Fimognari C, Foschi FG, Caputo F, Cantelli-Forti G, Stefanini GF, Gasbarrini G: Indicators of genetic damage in alcoholics: reversibility after alcohol abstinence. Hepatogastroenterology 1999, 46(27): 1664-1668.

44. Wu M, Zhao JK, Hu XS, Wang PH, Qin Y, Lu YC, Yang J, Liu AM, Wu $D L$, Zhang ZF, Frans KJ, van ' $t$ Veer P: Association of smoking, alcohol drinking and dietary factors with esophageal cancer in high- and low-risk areas of Jiangsu Province, China. World J Gastroenterol 2006, I 2(I I):1686-1693.

45. Sakata K, Hoshiyama Y, Morioka S, Hashimoto T, Takeshita T, Tamakoshi A: Smoking, alcohol drinking and esophageal cancer: findings from the JACC Study. J Epidemiol 2005, I5 Suppl 2:S212-9.

46. Yang CX, Wang HY, Wang ZM, Du HZ, Tao DM, Mu XY, Chen HG, Lei $Y$, Matsuo K, Tajima K: Risk factors for esophageal cancer: a case-control study in South-western China. Asian Pac J Cancer Prev 2005, 6(I):48-53.

47. de Martel C, Llosa AE, Farr SM, Friedman GD, Vogelman JH, Orentreich N, Corley DA, Parsonnet J: Helicobacter pylori infection and the risk of development of esophageal adenocarcinoma. $J$ Infect Dis 2005, I 9 I(5):76I-767.

48. Henrik Siman J, Forsgren A, Berglund G, Floren $\mathrm{CH}$ : Helicobacter pylori infection is associated with a decreased risk of developing oesophageal neoplasms. Helicobacter 200I, 6(4):310-316.

49. Wu DC, Wu IC, Lee JM, Hsu HK, Kao EL, Chou SH, Wu MT: Helicobacter pylori infection: a protective factor for esophageal squamous cell carcinoma in a Taiwanese population. Am J Gastroenterol 2005, 100(3):588-593.

50. Gao YT, McLaughlin JK, Blot WJ, Ji BT, Dai Q, Fraumeni JF Jr.: Reduced risk of esophageal cancer associated with green tea consumption. J Natl Cancer Inst 1994, 86(I I):855-858.
5I. Fujiki $\mathrm{H}$ : Green tea: Health benefits as cancer preventive for humans. Chem Rec 2005, 5(3): I19-132.

52. de Boer JG, Yang H, Holcroft J, Skov K: Chemoprotection against $\mathbf{N}$-nitrosomethylbenzylamine-induced mutation in the rat esophagus. Nutr Cancer 2004, 50(2): 168-173.

53. Sun CL, Yuan JM, Lee MJ, Yang CS, Gao YT, Ross RK, Yu MC: Urinary tea polyphenols in relation to gastric and esophageal cancers: a prospective study of men in Shanghai, China. Carcinogenesis 2002, 23(9): I 497-I503.

54. Hou Z, Sang S, You H, Lee MJ, Hong J, Chin KV, Yang CS: Mechanism of action of (-)-epigallocatechin-3-gallate: auto-oxidation-dependent inactivation of epidermal growth factor receptor and direct effects on growth inhibition in human esophageal cancer KYSE $\mathbf{1 5 0}$ cells. Cancer Res 2005, 65(I 7):8049-8056

55. Lin DX, Tang YM, Peng Q, Lu SX, Ambrosone CB, Kadlubar FF: Susceptibility to esophageal cancer and genetic polymorphisms in glutathione S-transferases $\mathrm{TI}, \mathrm{PI}$, and $\mathrm{MI}$ and cytochrome P450 2EI. Cancer Epidemiol Biomarkers Prev 1998, 7(II): $1013-1018$.

56. Wang AH, Sun CS, Li LS, Huang JY, Chen QS, Xu DZ: Genetic susceptibility and environmental factors of esophageal cancer in Xi'an. World J Gastroenterol 2004, I 0(7):940-944.

57. Stephens EA, Taylor JA, Kaplan N, Yang CH, Hsieh LL, Lucier GW, Bell DA: Ethnic variation in the CYP2EI gene: polymorphism analysis of 695 African-Americans, European-Americans and Taiwanese. Pharmacogenetics 1994, 4(4): 185-192.

58. Gao C, Takezaki T, Wu J, Li Z, Wang J, Ding J, Liu Y, Hu X, Xu T, Tajima K, Sugimura H: Interaction between cytochrome P-450 2EI polymorphisms and environmental factors with risk of esophageal and stomach cancers in Chinese. Cancer Epidemiol Biomarkers Prev 2002, I I ( I):29-34.

\section{Pre-publication history}

The pre-publication history for this paper can be accessed here:

\section{http://www.biomedcentral.com/1471-2407/6/287/pre} pub
Publish with Bio Med Central and every scientist can read your work free of charge

"BioMed Central will be the most significant development for disseminating the results of biomedical research in our lifetime. "

Sir Paul Nurse, Cancer Research UK

Your research papers will be:

- available free of charge to the entire biomedical community

- peer reviewed and published immediately upon acceptance

- cited in PubMed and archived on PubMed Central

- yours - you keep the copyright

Submit your manuscript here:

http://www.biomedcentral.com/info/publishing_adv.asp
BioMedcentral 